\title{
TU/e EmonONEN

\section{Influence of surfactant type and concentration on the drainage of liquid films}

\section{Citation for published version (APA):}

Baets, P. J. M., \& Stein, H. N. (1992). Influence of surfactant type and concentration on the drainage of liquid films. Langmuir, 8(12), 3099-3101. https://doi.org/10.1021/la00048a040

DOI:

10.1021/la00048a040

Document status and date:

Published: 01/01/1992

\section{Document Version:}

Publisher's PDF, also known as Version of Record (includes final page, issue and volume numbers)

\section{Please check the document version of this publication:}

- A submitted manuscript is the version of the article upon submission and before peer-review. There can be important differences between the submitted version and the official published version of record. People interested in the research are advised to contact the author for the final version of the publication, or visit the $\mathrm{DOI}$ to the publisher's website.

- The final author version and the galley proof are versions of the publication after peer review.

- The final published version features the final layout of the paper including the volume, issue and page numbers.

Link to publication

\section{General rights}

Copyright and moral rights for the publications made accessible in the public portal are retained by the authors and/or other copyright owners and it is a condition of accessing publications that users recognise and abide by the legal requirements associated with these rights.

- Users may download and print one copy of any publication from the public portal for the purpose of private study or research.

- You may not further distribute the material or use it for any profit-making activity or commercial gain

- You may freely distribute the URL identifying the publication in the public portal.

If the publication is distributed under the terms of Article 25fa of the Dutch Copyright Act, indicated by the "Taverne" license above, please follow below link for the End User Agreement:

www.tue.nl/taverne

Take down policy

If you believe that this document breaches copyright please contact us at:

openaccess@tue.nl

providing details and we will investigate your claim. 


\title{
Influence of Surfactant Type and Concentration on the Drainage of Liquid Films
}

\author{
P. J. M. Baets and H. N. Stein* \\ Department of Chemical Engineering, Eindhoven University of Technology, P.O. Box 513, \\ 5600 MB Eindhoven, The Netherlands
}

Received April 6, 1992. In Final Form: September 9, 1992

\begin{abstract}
Measurements of drainage are reported of films drawn from surfactant solutions in a vertical frame. The drainage was measured either by interference or by the downward velocity of polystyrene particles. The latter could be observed by means of light extinction. The drainage time of films of $1.5 \mu \mathrm{m}$ thickness (measured with polystyrene particles) was found to be independent of the film height within the investigated range (13-17 $\mathrm{mm}$ ) and was proportional to the bulk viscosity for solutions containing water/glycerol and CTAB. The drainage rate is independent of concentration above the critical micelle concentration (cmc), and films drain faster below the cmc. Liquid films drawn from CTAB solutions are mobile below the cmc. Thicker and thinner regions at the film/Plateau border transition alternate; the corresponding wavelength does not vary strongly with the bulk viscosity. From the drainage time of films drawn from solutions with a complicated rheological behavior, the effective shear stress and shear rate in the dominant process of film thinning can be estimated.
\end{abstract}

\section{Introduction}

The drainage of liquid films is important for processes involving foams and emulsions.

There are several methods to study the drainage of, for example, a foam. ${ }^{1-3}$ We used in our investigations a Fizeau interferometer constructed analogously to the one Mysels used, thus for a vertical foam film. Mysels et al. ${ }^{3}$ already showed that there are several drainage types for foam films. Most of the films studied in our work were mobile films (except for the CTAB/SA combination). Later work confirmed Mysels' view that marginal regeneration is the major mechanism of film thining in this type of film.

Therefore we focused our attention on marginal regeneration. We investigated the influence of type of surfactant on the drainage rate and we also measured the wavelenth of the "peacock feathers" in the interference fringes caused by alternating thick/thin regions at the film/Plateau border transition as a function of the bulk viscosity and film thickness.

The "peacock feathers" only occur in vertical films. Nonhomogeneities have been observed in horizontal films. ${ }^{5}$ These nonhomogeneities are supposed to act as surface waves pumping liquid out of the film, increasing the drainage rate. Sharma and Ruckenstein ${ }^{6,7}$ gave a mathematical description for this process in which, however, no a priori reason could be given for an asymmetric character of the surface waves as required for a pumping action. There are in addition some problems in applying the equations (derived for horizontal films) to vertical ones, since the equations do not account for surface tension gradients. Another complication is that gravity acts in verticle films directly on the nonhomogeneities, which

(1) Brady, A. P.; Ross, S. J. Am. Chem. Soc. 1944, 66, 1348-1356. 725 .

(2) Rácz, Gy.; Erdös, E.; Koczó, K. Colloid Polym. Sci. 1982, 260, 720-

(3) Mysels, K. J.; Shinoda, K.; Frankel, S., Soap films studies of their thinning and a bibliography; Pergamon Press: London, 1959; Chapter 2-1.

(4) Hudales, J. B. M.; Stein, H. N. J. Colloid Interface Sci. 1990, 138 (2), 354-364.

(5) Radoev, B. P.; Scheludko, A. D.; Manev, E. D. J. Colloid Interface Sci. 1983,95 (1), 254-265. 1-13.

Ruckenstein, E.; Sharma, A. J. Colloid Interface Sci. 1987, 119

(7) Sharma, A. and Ruckenstein, E. Colloid Polym. Sci. 1988, 266, $60-69$. causes the thin parts to flow upward (similar to Archimedes' law).

\section{Experimental Section}

Materials. The following chemicals were used without further purification: SDBS (Nansa $1260>99.2 \%$ ex Albright+Wilson); sodium p-(3-dodecyl)benzenesulfonate (>99\%, KSLA); sodium 3-(3-dodecyl)-6-methylbenzenesulfonate (KSLA); sodium 2-(3dodecyl)-4,5-dimethylbenzenesulfonate (KSLA); CTAB (>99\% ex Janssen Chimica); octanol ( $>99 \%$ ex Merck); pentanol (>99\% ex Merck); salicylic acid (p.a. ex U.C.B); glycerol ( $>98 \%$ ex Merck); polystyrene particles ( $d=1500 \mathrm{~nm}, \sigma=240 \mathrm{~nm}$ ); distilled water (twice).

Apparatus. Most solutions were measured in a Fizeau interferometer constructed analogously to the apparatus used by Mysels. ${ }^{3}$ In addition to the observation method by reflected light, our apparatus has the possibility of observing transmitted light. This is useful in the case of surfactant solutions with a complex rheological behavior, such as the CTAB/SA solutions (Strivens ${ }^{8}$ ). This gives rise to nonuniform film thicknesses, the (rigid) film can have different thicknesses at a certain time and height, this in contrast with a mobile film. The interference pattern is then too complicated to be analyzed. In such cases, measurements of the drainage rate can be performed by following the downward motion of monodisperse hydrophilic polystyrene particles $(1500 \mathrm{~nm}$ ) which cannot be present in a film which is thinner than the particle diameter. ${ }^{2}$ The particles therefore mark the places in the film above which the film is thinner than 1500 $\mathrm{nm}$. By estimation of an average height of the (particle free film)/(particle containing film) transition at different times, a drainage rate can be measured.

We used for our experiment two frames (see Figure 1). A metal frame with four sharp-angled legs was constructed to form four soap films, with a fifth film in the middle. The fifth film (the film we are measuring) has two free Plateau borders. A glass frame (two legs) was used for the branched SDBS solutions which did not form soap films in the metal frame. The length of the legs (in both frames) is $2.0 \mathrm{~cm}$. For the sodium p-(3dodecyl) benzenesulfonate it was even necessary to bring the $\mathrm{pH}$ under the IEP of the glass (with $\mathrm{HCl}$ ), probably in order to increase the wetting of the solution on the frame.

\section{Results}

In Figure 2, the height at which the film has a thickness of $1500 \mathrm{~nm}$ is shown as a function of time. Polystyrene

(8) Strivens, T. A. Colloid Polym. Sci. 1989, 267, 269-280.

(9) Baets, P. J. M.; Stein, H. N. To be submitted for publication. 


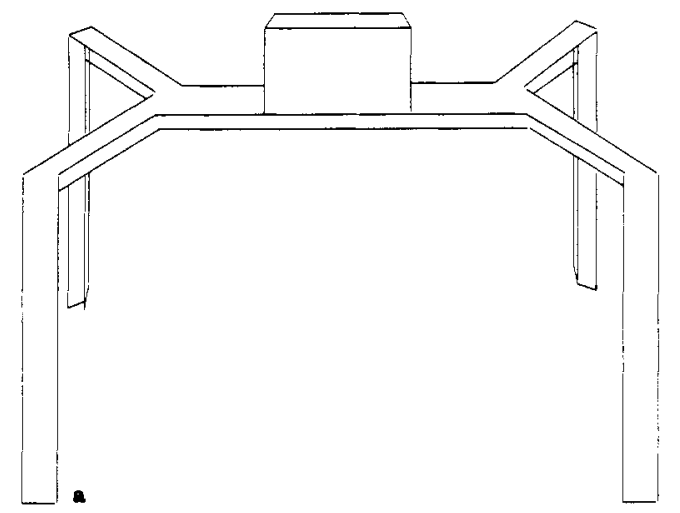

Figure 1. (a) The metal frame. (b) The glass frame.

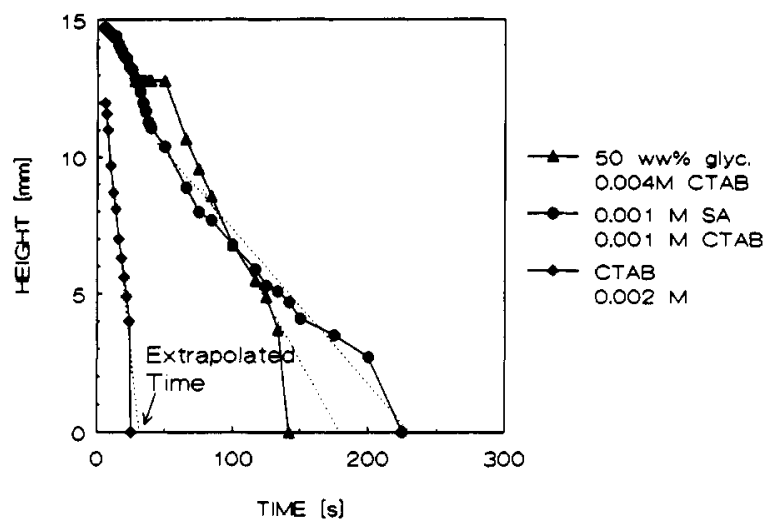

Figure 2. Drainage of several soap solutions (height-time).

Table I. Drainage Time as a Function of Film Heighte

\begin{tabular}{|c|c|c|c|c|c|c|c|}
\hline \multicolumn{4}{|c|}{$\begin{array}{c}\text { CTAB } \\
0.002 \mathrm{M}\end{array}$} & \multicolumn{4}{|c|}{$\begin{array}{c}\text { sodium } p \text {-(3-dodecyl)- } \\
\text { benzenesulfonate } \\
0.003 \mathrm{M} ; \mathrm{pH}=2 \text { with } \mathrm{HCl}\end{array}$} \\
\hline $\begin{array}{c}\text { height, } \\
\text { mm }\end{array}$ & $\begin{array}{c}\text { time, } \\
\mathbf{8}\end{array}$ & $\sigma, \mathrm{s}$ & $n$ & $\begin{array}{c}\text { height, } \\
\text { mm }\end{array}$ & $\begin{array}{c}\text { time, } \\
8\end{array}$ & $\sigma, 8$ & $n$ \\
\hline $\begin{array}{r}6.57 \\
10.37 \\
12.37 \\
13.07 \\
17.30\end{array}$ & $\begin{array}{l}27.0 \\
25.6 \\
23.6 \\
22.3 \\
22.8\end{array}$ & $\begin{array}{l}1.0 \\
2.1 \\
0.4 \\
0.5 \\
0.3\end{array}$ & $\begin{array}{l}2 \\
7 \\
5 \\
3 \\
2\end{array}$ & $\begin{array}{r}8.46 \\
9.66 \\
12.58 \\
14.23 \\
15.13 \\
17.08\end{array}$ & $\begin{array}{l}6.2 \\
6.4 \\
7.2 \\
8.7 \\
8.2 \\
8.6\end{array}$ & $\begin{array}{l}0.4 \\
0.3 \\
0.2 \\
0.1 \\
0.2 \\
0.3\end{array}$ & $\begin{array}{l}6 \\
6 \\
4 \\
4 \\
5 \\
6\end{array}$ \\
\hline
\end{tabular}

- Time measured until the film is free of PS.

particles were used for the measurements of the CTAB/ SA solution; the other two lines were obtained by means of interferometry. Extrapolation of the straight upper part of the drainage lines in Figure 2 gives a time (seconds) at zero height, which can be taken as a measure for the drainage rate. Of the solutions measured the only one which does not give a straight part in the drainage line was the CTAB/SA combination. This is ascribed to its complicated rheological behavior. 8,10

We found that this drainage time does not depend on the initial film height for heights in the interval 13-17 mm (see Table I). We verified this for two surfactants, CTAB $(0.002 \mathrm{M})$ and sodium $p$-(3-dodecyl)benzenesulfonate $(0.003 \mathrm{M})$ in a glass frame, with traces of PS particles 1500 $\mathrm{nm}$. The drainage time listed is the time after film formation when the film is free of solid particles.

Table II lists both the extrapolated times and the bulk viscosity of the solutions. The temperature is the temperature of the drainage experiment. The viscosity was calculated from a viscosity measurement at that temper-

(10) Wunderlich, A. M.; Brunn, P. O. Colloid Polym. Sci. 1989, 267, $627-636$.

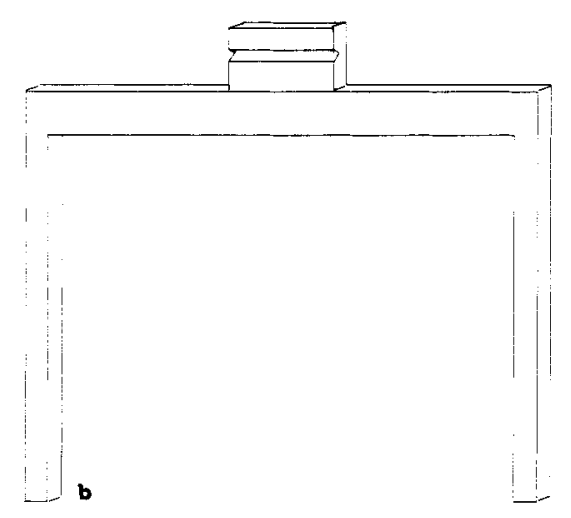

Table II

Drainage of the Surfactant Solutions Measured in a Glass Frame

\begin{tabular}{|c|c|c|c|c|c|c|}
\hline \multirow[b]{2}{*}{ solution } & \multirow[b]{2}{*}{$\begin{array}{l}\text { conc, } \\
\mathrm{mol} / \mathrm{L}\end{array}$} & \multicolumn{2}{|c|}{ drainage } & \multirow[b]{2}{*}{$\begin{array}{l}\text { height, } \\
\text { mm }\end{array}$} & \multirow{2}{*}{$\begin{array}{l}\text { vis- } \\
\text { cosity, } \\
\mathrm{mPa} 8\end{array}$} & \multirow[b]{2}{*}{ temp, } \\
\hline & & $\begin{array}{c}\text { time, } \\
8\end{array}$ & $\begin{array}{c}\mathrm{vel}, \\
\mathrm{mm} / \mathrm{s}\end{array}$ & & & \\
\hline $\begin{array}{c}\text { Na } p \text {-(3-dodec)-BS, } \\
\text { pH }=2(\mathrm{HCl})\end{array}$ & 0.003 & 8.7 & 1.63 & 14.2 & & 25.4 \\
\hline $\begin{array}{l}\text { Na 3-(3-dodec)-6- } \\
\text { methyl-BS }\end{array}$ & 0.0054 & 28.8 & 0.47 & 14.1 & 0.94 & 24.0 \\
\hline $\begin{array}{l}\mathrm{Na} 2 \text {-(3-dodec)-4,5- } \\
\text { dimethyl-BS }\end{array}$ & 0.0078 & 24.3 & 0.53 & 14.0 & 0.83 & 29.7 \\
\hline
\end{tabular}

\begin{tabular}{|c|c|c|c|c|c|c|}
\hline \multirow[b]{2}{*}{ solution } & \multirow[b]{2}{*}{$\begin{array}{l}\text { conc, } \\
\mathrm{mol} / \mathrm{L}\end{array}$} & \multicolumn{2}{|c|}{ drainage } & \multirow[b]{2}{*}{$\begin{array}{c}\text { height, } \\
\text { mm }\end{array}$} & \multirow{2}{*}{$\begin{array}{l}\text { vis- } \\
\text { cosity, } \\
\mathrm{mPa} \text { s }\end{array}$} & \multirow[b]{2}{*}{ temp, } \\
\hline & & $\begin{array}{c}\text { time, } \\
\mathrm{s}\end{array}$ & $\begin{array}{c}\mathrm{vel}, \\
\mathrm{mm} / \mathrm{s}\end{array}$ & & & \\
\hline CTAB & 0.0006 & 29.9 & 0.361 & 11.9 & 0.91 & 24.3 \\
\hline CTAB & 0.0008 & 30.6 & 0.392 & 12.4 & 0.90 & \\
\hline CTAB & 0.002 & 32.7 & 0.440 & 14.3 & 0.91 & 24.3 \\
\hline CTAB & 0.02 & 34.1 & 0.413 & 13.8 & 0.96 & 25.2 \\
\hline $\begin{array}{l}\text { CTAB in } 50 \% \\
(\text { ww) glycerol }\end{array}$ & 0.004 & 184 & 0.101 & 12.8 & 4.5 & 28.4 \\
\hline $\begin{array}{l}\text { CTAB + } \\
\text { pentanol }\end{array}$ & $\begin{array}{l}0.002 \\
0.002\end{array}$ & 33.3 & 0.430 & 14.7 & 0.90 & 24.9 \\
\hline $\begin{array}{l}\text { CTAB + } \\
\text { octanol }\end{array}$ & $\begin{array}{l}0.002 \\
0.002\end{array}$ & 36.8 & 0.407 & 14.3 & 0.90 & 24.9 \\
\hline $\begin{array}{l}\text { CTAB + } \\
\text { salicylic acid }\end{array}$ & $\begin{array}{l}0.001 \\
0.001\end{array}$ & 231 & 0.063 & 14.9 & $a$ & 24.0 \\
\hline SDBS & 0.003 & 28.4 & 0.505 & 13.9 & 0.89 & 25.1 \\
\hline
\end{tabular}

a See Figure 3.

ature $\left( \pm 1{ }^{\circ} \mathrm{C}\right)$. Most solutions were measured with a Ubbelohde viscosimeter, except for the CTAB/SA solution. The viscosity of the CTAB/water/glycerol solution was also measured with the Rheometrics RFS II system and found to be Newtonian (see Figure 3). The rheology of the CTAB/SA system has been investigated by Strivens ${ }^{8}$ and by Wunderlich and Brunn. ${ }^{10}$ The data of Wunderlich and Brunn however could not be used, since the concentrations were different from those employed in the present work. Figure 4 gives the measurements performed on a $0.001 \mathrm{M}$ CTAB/SA solution, with regard to the steady flow viscosity. A double gap 40/50 was used with the Bohlin measurements. Measurements were performed both with increasing shear rate ( $\mathrm{L}-\mathrm{H}$ measurements) and with decreasing shear rate (H-L measurements). We used single concentric cylinders in the Deer viscosimeter (2.00$1.80 \mathrm{~cm} \times 6.50 \mathrm{~cm}$ ) and applied at least $15 \mathrm{~min}$ shear before every measurement.

The wavelength of the thin film spots in the CTAB/ water and the CTAB/water $/ 50 \%(w / w)$ glycerol mixtures was measured near the horizontal film/bulk liquid transition at the lower side of the film. The results are given in Table III. Figure 5 is an example of an analyzed picture. 


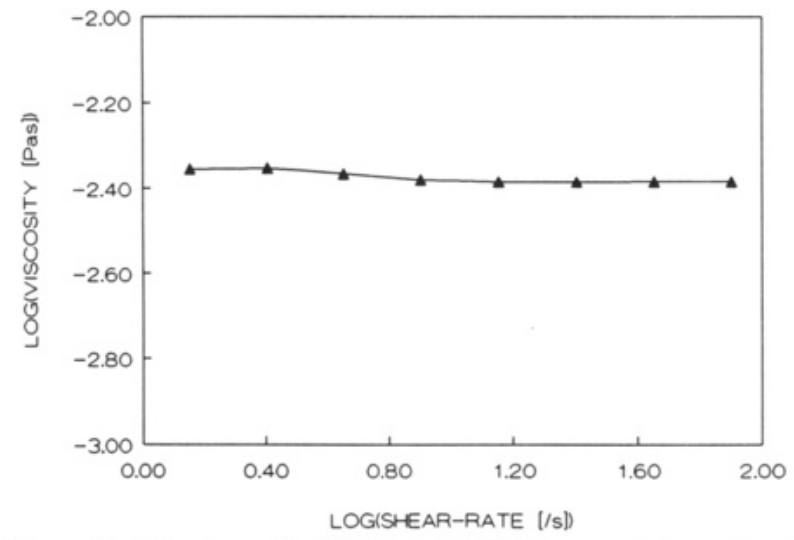

Figure 3. Rheology of a CTAB $(0.004 \mathrm{M})$ in water/glycerol $50 \%$ solution at $30^{\circ} \mathrm{C}(\log$ [shear rate]-log [viscosity]).

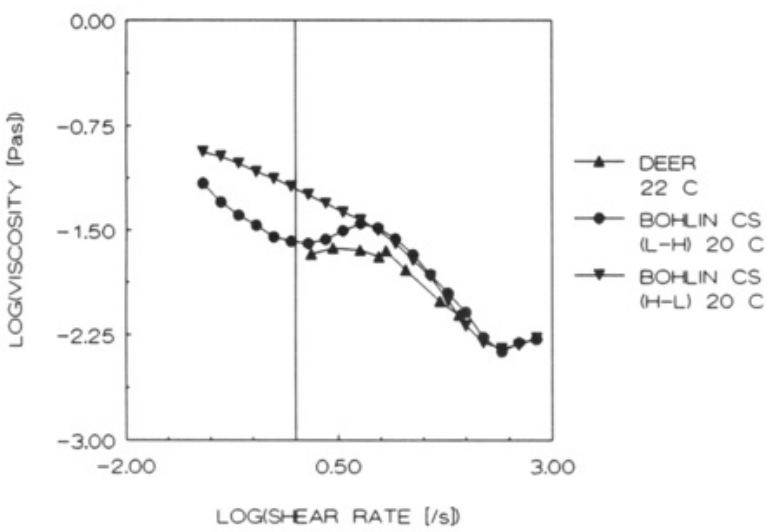

Figure 4. Rheology of CTAB/SA $(0.001 \mathrm{M})$ in water (log [shear rate]-log [viscosity]).

Table III. Wavelength of Marginal Regeneration at the Bottom of a Film

\begin{tabular}{ccccc}
\hline \multicolumn{2}{c}{$\begin{array}{c}\text { CTAB [0.002 M] } \\
\text { in water }\end{array}$} & & \multicolumn{2}{c}{$\begin{array}{c}\text { CTAB [0.005 M] } \\
\text { in glycerol/water }\end{array}$} \\
\cline { 1 - 2 } \cline { 5 - 6 } $\begin{array}{c}\text { thickness, } \\
\text { nm }\end{array}$ & $\begin{array}{c}\text { wavelength, } \\
\text { mm }\end{array}$ & & $\begin{array}{c}\text { thickness, } \\
\text { nm }\end{array}$ & $\begin{array}{c}\text { wavelength, } \\
\text { mm }\end{array}$ \\
\hline 1539 & 0.86 & & 781 & 0.47 \\
1232 & 0.79 & & 391 & 0.35 \\
513 & 0.62 & & 293 & 0.31 \\
410 & 0.62 & & 195 & 0.32
\end{tabular}

\section{Discussion}

The CTAB solutions below the critical micelle concentration (cmc) did not give rigid films and drained faster than solutions above the cmc. The drainage time above the $\mathrm{cmc}$ was no longer a function of the concentration (except for a slight increase which can be ascribed to the increase in viscosity). The measurements below the $\mathrm{cmc}$ however were very tedious and were performed with great care in order to prevent traces of paper tissue and other particles from entering the solution. We found that sometimes rigid films were formed below the $\mathrm{cmc}$ if this precaution was not taken. This gave rise to poor reproducibility. Rigidity was found to be due to impurities by other researchers as well. ${ }^{3,11}$

We measured the CTAB/SA system in a Deer and a Bohlin viscosimeter and found our results to be in agreement with the measurements of Strivens. ${ }^{8}$ At low shear rates, hysteresis was observed with the Bohlin viscosimeter.

There is (as far as we know) no theory which describes the drainage of mobile vertical films quantitatively.

(11) Prins, A.; Arcuri, C.; Van den Tempel, M. J. Colloid Interface Sci. $1967,24,84-90$.

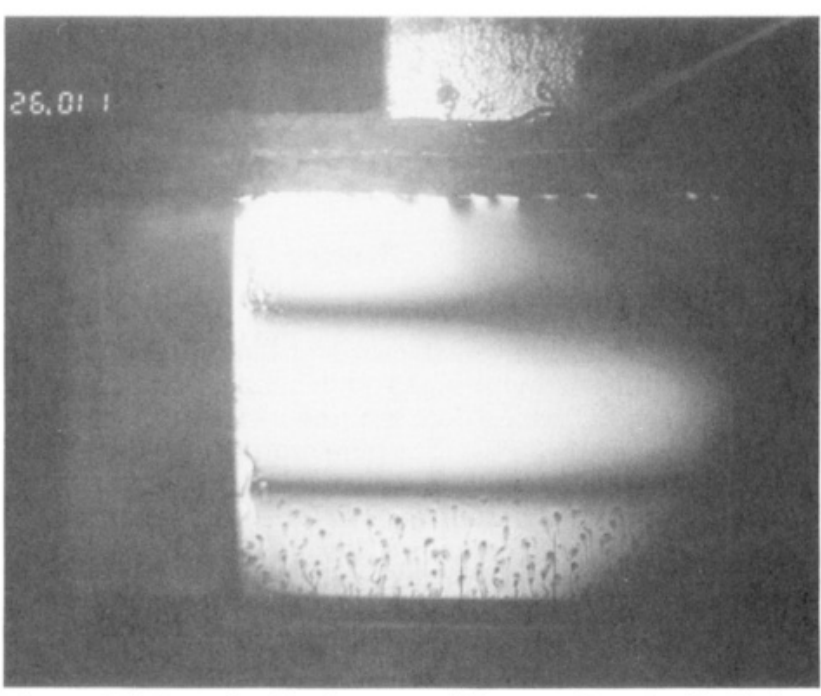

Figure 5. Example of a picture used for wavelength calculation.

Seeking an easy way to comprise the measurements, we considered two possibilities: the drainage velocity and the (extrapolated) drainage time. Although both options describe the drainage process fairly well, we prefer to use the drainage time because it is independent of height.

A significant effect but not a very strong effect of viscosity and film thickness was found on the wavelength of marginal regeneration at the bottom film/Plateau border boundary. The wavelength in a horizontal (SDS $+\mathrm{NaCl}$ ) film was measured by Radoev et al. ${ }^{5}$ The diameter of the nonhomogenities was slightly larger than $0.005 \mathrm{~cm}$. This is 1 order of magnitude smaller than the wavelength found in our systems (about $0.07 \mathrm{~cm}$ ).

The measurement of the glycerol/water/CTAB mixture indicates the drainage-time scales (almost) proportional to the bulk viscosity, in agreement with the theory of Ruckenstein and Sharma. ${ }^{6,7}$ The proportionality can be used to estimate the effective shear rate and shear stress, in the dominant process of film thinning as follows. For the CTAB/SA sample we found a drainage time of $231 \mathrm{~s}$. This indicates that the viscosity of the solution is about $6.4 \mathrm{mPa}$ s. The shear rate in this process therefore is (see Figure 4) $100 / \mathrm{s}$. The shear stress therefore is $0.64 \mathrm{~N} / \mathrm{m}^{2}$.

\section{Conclusions}

The drainage of thin liquid CTAB films does not depend on the film height within the range $13-17 \mathrm{~mm}$. The drainage of a CTAB film above the $\mathrm{cmc}$ is not a function of the concentration $(0.001-0.02 \mathrm{M})$. The drainage below the cmc shows a slight increase with a decrease of concentration.

The drainage rate was found to be inversely proportional to the viscosity. The shear-stress causing the drainage was estimated to be $0.64 \mathrm{~N} / \mathrm{m}^{2}$.

The wavelength of the film spots in marginal regeneration was 1 order of magnitude larger than the wavelength found in horizontal films.

Acknowledgment. This work was made possible by financial support from Stichting Technische Wetenschappen and Voorbij Beton b.v. We thank Dr. N. van Os for the donation of three SDBS samples, and A. J. G. van Diemen for placing polystyrene particles at our proposal.

Registry No. CTAB, 57-09-0; SD, 151-21-3; SA, 69-72-7; glycerol, 56-81-5; octanol, 111-87-5; pentanol, 71-41-0; sodium p-(3-dodecyl)benzenesulfonate, 2212-50-2; sodium 3-(3-dodecyl)6-methylbenzenesulfonate, 142276-56-0; sodium 2-(3-dodecyl)4,5-dimethylbenzenesulfonate, 144002-86-8. 